Société d'histoire de la révolution de 1848 et des

révolutions du XIXe siècle

$9 \mid 1993$

Utopies au XIXe siècle

\title{
Le premier rayonnement en France des idées d'Auguste Comte (1824-1848) : les milieux, les institutions, les hommes
}

Mirella Larizza-Lolli

\section{OpenEdition}

\section{Journals}

Electronic version

URL: http://journals.openedition.org/rh19/71

DOI: $10.4000 /$ rh 19.71

ISSN: $1777-5329$

\section{Publisher}

La Société de 1848

\section{Printed version}

Date of publication: 1 June 1993

ISSN: 1265-1354

\section{Electronic reference}

Mirella Larizza-Lolli, « Le premier rayonnement en France des idées d'Auguste Comte (1824-1848) : les milieux, les institutions, les hommes », Revue d'histoire du XIXe siècle [Online], 9 | 1993, Online since 09 September 2008, connection on 03 May 2019. URL : http://journals.openedition.org/rh19/71 ; DOI : $10.4000 /$ rh19.71

This text was automatically generated on 3 May 2019.

Tous droits réservés 
Le premier rayonnement en France des idées d'Auguste Comte (1824-1848) : les milieux, les institutions, les hommes

Mirella Larizza-Lolli

\section{ABSTRACTS}

No abstract available by now

Pas de résumé disponible actuellement

INDEX

Mots-clés: Utopie, Histoire intellectuelle, Positivisme 